\title{
OBSERWACJA I TRWANIE - O LIRYCZNOŚCI WIERSZY KS. JANUSZA ST. PASIERBA
}

Przełom w myśleniu o dziele literackim nastąpił w romantyzmie. Zaczęto wtedy traktować twórczość jako spontaniczny wyraz „reakcji człowieka na rzeczywistość wewnętrzną własnej osobowości i na prawdę świata, który go na zewnątrz otacza"1. Ten zwrot w myśleniu o literaturze wiązał się nie tylko z rozluźnieniem kategoryzowania rodzajowego (podział na lirykę, epikę i dramat), lecz także z podkreśleniem wagi jednostkowej reakcji człowieka na otaczającą go rzeczywistość i własne życie wewnętrzne. W centrum tego myślenia znajduje się więc osoba - podmiot działający. Ten sposób rozumowania stał się znaczącym dziedzictwem refleksji nad literaturą i wpisał się na stałe w myślenie o dziele literackim (szczególnie poezji) do tego stopnia, że dziś kategoria mówiącego podmiotu podejmowana jest w niemal każdym dyskursie dotyczącym tekstu. Twórczość poetycka jest miejscem szczególnej obecności podmiotu. Tezę tę potwierdza chociażby słownikowa definicja liryki, w której czytamy, że jest to jeden z podstawowych rodzajów literackich:

obejmujący utwory, których domenę tematyczną stanowią przede wszystkim wewnętrzne przeżycia, doznania, emocje i przekonania j e d n o s t k i [podkr. K.B.] przekazywane za pośrednictwem wypowiedzi monologicznej o silnym nacechowaniu s u b i e k ty w n y m [podkr. K.B.], podporządkowanej funkcji ekspresywnej. Ośrodkiem utworu lirycznego bywa najczęściej podmiot liryczny (inaczej ,ja” liryczne), którego uczucia lub myśli organizują całokształt przedstawienia; sytuacja podmiotu jest $\mathrm{w}$ takim utworze głównym wyznacznikiem kompozycji².

Czesław Zgorzelski, Zarysy i szkice literackie, Warszawa 1988, s. 8.

2 Janusz Sławiński, Liryka, hasło w: Michał Głowiński, Teresa Kostkiewiczowa, Aleksandra Okopień-Sławińska, Janusz Sławiński, Słownik terminów literackich, pod red. Janusza Sławińskiego, wyd. 5 bez zmian, Wrocław 2008, s. 278-280. 
Ośrodkiem utworu lirycznego, a więc i nośnikiem liryczności jest podmiot mówiący. To jego obserwacje i doświadczenia są dane odbiorcy. Skupienie na jednostkowych doznaniach jest także bardzo ważną cezurą w myśleniu o opisowości i referencyjności dzieł literackich.

Ważnym problemem w nauce o literaturze jest kwestia samoświadomości twórczej autora. Abstrahując od sporów teoretycznych, chciałabym przywołać głos Ostapa Ortwina, który podkreśla dystansowanie się podejmującego czynności twórcze autora wobec własnych przeżyć, czego rezultatem jest utwór zindywidualizowany, ale o zobiektywizowanym wyrazie ${ }^{3}$. Ortwin tak komentuje tę sprawę:

Poemat liryczny, wykwit wynurzeń najosobistszych i najskrajniej subiektywnych, jest przetworem ulotnej, pierzchliwej, mijającej chwili. Zarazem jednak, jako dzieło sztuki, dochodzi do pełni znaczenia i wartości estetycznej wtedy dopiero, gdy umie za pomocą środków i metod artystycznych wznieść się ponad tę znikomość doraźnej chwili i ponad zmienną, nietrwałą doczesność jednostki, gdy z potocznych, przygodnych i przypadkowych pierwiastków czysto indywidualnego przeżycia wysnuwa ich wiekuisty, ogólnoludzki wątek, gdy w wiecznotrwałym materiale języka uzewnętrznia je, przygważdża raz na zawsze i upowszechnia, czyniąc je dla wszystkich uchwytnymi i zrozumiałymi ${ }^{4}$.

W przytoczonej wypowiedzi warto zwrócić uwagę na przejście od drobnej obserwacji do zinternalizowanego, ale i zobiektywizowanego doświadczenia przelanego na papier. W przypadku poezji ks. Janusza St. Pasierba problem ten jest wyjątkowo wyraźny. Wiersze bardzo często dotyczą jednego zaobserwowanego momentu, który następnie jest odnoszony do sytuacji ogólniejszej, wykraczającej ponad to, co zauważone. Pomocna okazuje się więc wskazówka: „czynności interpretacyjne winny więc zmierzać do uchwycenia tej swoistości podmiotu

\footnotetext{
3 Mam tu na myśli m.in. szkice: Thomasa Stearne'a Eliota, Tradycja i talent indywidualny, w: Teoria badań literackich za granica. Antologia, wybór, rozprawa wstępna, komentarze Stefanii Skwarczyńskiej, t. II: Od przełomu antypozytywistycznego do roku 1945, cz. II: Od fenomenologii do egzystencjalizmu. Estetyzm i New Criticism, Kraków 1981, s. 397-408, i Ostapa Ortwina, O liryce $i$ wartościach lirycznych, w: tegoż, Żywe fikcje. Studia o prozie, poezji i krytyce, oprac. Jadwiga Czachorowska, wstępem poprzedził Michał Głowiński, Warszawa 1970, s. 105-116.

${ }^{4}$ Ostap Ortwin, O liryce $i$ wartościach lirycznych, dz. cyt., s. 105.
} 
mówiącego [...]. Jego obecność zaś [...] odciśnięta zostaje w przestrzeni od najgłębszych sensów poczynając, po pierwsze i zewnętrzne sfery oddziaływania na czytelnika [...]"5.

Poezja księdza Pasierba już przy pierwszym zetknięciu daje się poznać jako szczególnie naznaczona podmiotowością autora. Warto także w tym miejscu odnotować, że wszystkie tomiki jego wierszy łączy pewien rodzaj ciepłego, przyjaznego człowiekowi i kulturze spojrzenia nawet jeśli tekst dotyczy cierpienia i samotności. Doświadczenie percypowania rzeczywistości Pasierb przekłada na tkankę poetycką, utrwalając pojedyncze doznania i dokonując myślowych przeniesień na poziom refleksji głębszych, wykraczających poza doraźność notatki. Przykładem może być wiersz staruszka w muzeum, który pochodzi z tomu Zdejmowanie pieczęci:

staruszka w galerii

tuż przed zamknięciem

siwa umęczona

rencistka pewnie

a nie milionerka

jak Sokrates w więzieniu

grający na lirze

wzruszająca

może teraz dopiero

znalazła czas

gdy czasu już nie ma

a na pewno trzeba

przed długą podróżą

\footnotetext{
Bernadetta Kuczera-Chachulska, Kategoria liryczności a problemy wartościowania, w: Wartość $i$ sens. Aksjologiczne aspekty teorii interpretacji, studia pod red. Andrzeja Tyszczyka, Edwarda Fiały, Ryszarda Zajączkowskiego, Lublin 2003, s. 142.
} 
sprawdzić jak wygląda

Jezus Matka Boska

aniołowie niebo ${ }^{6}$

Wiersz jest pozornie wyłącznie krótką relacją z zauważonej sytuacji. Podano czas i miejsce zdarzenia: wszystko dzieje się w galerii, na chwilę przed jej zamknięciem. Więcej szczegółów nie ma. Suche sprawozdanie obejmuje jednak tylko pierwszą strofę. Podmiot mówiący przygląda się staruszce. Obserwujemy kobietę jego oczami - jest siwa i zmęczona. Mówiący jej nie zna, ale wyraża przypuszczenie, że może być ona rencistką. Poza tą niepewnością wyraża obserwator coś jeszcze - sygnalizuje, że wobec całej tej sytuacji pragnie zachować dystans - uściślenie: ,a nie milionerka” ujawnia niepodszyty kpiną humor. Ważny okazuje się zmysł obserwacyjny. Wojciech Kudyba charakteryzował wysiłek, jaki podejmuje podmiot mówiący w patrzeniu na człowieka i kulturę przełamywanie reportażu? Zwracał bowiem uwagę na „naoczność obserwacji i dbałość o warstwę faktograficzną", przy założeniu, że ,obserwacja nie staje się tu celem, lecz środkiem: służy do odsłonięcia «drugiego dna» opisywanych zjawisk"9. Podmiot mówiący pozostaje aktywnym interpretatorem rzeczywistości, który nie poprzestaje na relacji. W tej strofie dystans wobec obserwowanej kobiety widać nie tylko w zakończeniu utworu, lecz także w pewnego rodzaju ciepłej ironii (jakże innej niż na przykład ironia Szymborskiej!).

Trzecia strofa to refleksja na temat czasu. Sytuacja kobiety „streszczona” została za pomocą efektownego paradoksu: ,znalazła czas / gdy czasu już nie ma". Kwestia czasowości i przemijania staje się osią tematyczną tego utworu. Kobieta charakteryzowana jest przez czynności, które wykonuje, i czas, jaki jej pozostał na ich wykonanie. Możność ograniczona jest niemożnością, która ma pojawić się niebawem.

Janusz St. Pasierb, Zdejmowanie pieczęci, Pelplin 2006, s. 29.

7 Wojciech Kudyba, Rana, która przyzywa Boga. O twórczości poetyckiej Janusza St. Pasierba, Lublin 2006, s. 25-30.

8 Tamże, s. 26.

9 Tamże, s. 29. 
Ostatnia część utworu puentuje rozszerzenie spojrzenia na obserwowaną sytuację. Kobieta jest ,przed długą podróżą”. Istotę tej wyprawy wyjaśniają kolejne wersy: „trzeba [...] sprawdzić jak wygląda / Jezus Matka Boska / aniołowie niebo". O rzeczach ostatecznych mówi się więc w sposób żartobliwy, ale „sprawę" starszej kobiety traktuje się niezwykle serio. W obrębie tej, zdaje się, lekkiej formy jest miejsce także dla mówienia o wieczności. Jest ono możliwe dzięki osobliwemu rozszerzeniu pola widzenia, które zapewnia trwanie zanotowanej, migawkowej scenie. Perspektywa absolutna nadaje głębię obserwowanemu zdarzeniu, nie tylko pozwala na petryfikowanie zanurzonej w czasie rzeczywistości, lecz także sprawia, że obraz ten jest za każdym razem wyjątkowo żywy. Dotyk metafizyki animuje przedstawianą scenę.

Przykład tego wiersza potwierdza tezę o rozszerzaniu perspektywy zwykłego obserwatora - wyprawa staruszki do muzeum została podniesiona do rangi poszukiwania prawdy, poznania nieznanego. Ciepła ironia, której trudno nie zauważyć w postawie podmiotu mówiącego, wskazuje na żywe zainteresowanie sprawami ludzkimi. Bohaterka traktowana jest zawsze serio, mimo że przypisuje się jej nieco naiwne myślenie i sposób oglądu spraw związanych z przemijaniem. Mówiący zachowuje dystans obserwatora, jednocześnie pozostając blisko swojej bohaterki. Zwyczajność sytuacji pogłębiona jest perspektywą bliskiej wieczności. Warto zwrócić uwagę, że nie jest to liryka roli. Podmiot mówiący zachowuje swój status obserwatora. Czasem się dziwi, czasem zastanawia, innym razem coś przypuszcza, zawsze jednak interpretuje sytuacje pełen życzliwego zainteresowania dla człowieka i jego spraw. Istotne jest to, że swój ogląd wzbogaca perspektywą sakralną.

Zupełnie inny sposób notowania codziennego doświadczenia pokazuje wiersz prywatnie z tomu Czarna skrzynka:

nie ma się gdzie schować

po otrzymaniu takiej wiadomości

w naszych mieszkaniach nie ma prywatnych kaplic

można tylko na chwilę zamknąć się w łazience 
usiąść na brzegu wanny i powtarzać

Jezusie Nazareński Jezusie

to przecież nie może być prawda ${ }^{10}$

W wierszu widoczny jest problem ludzkiego osamotnienia w obliczu niepomyślnej wiadomości. Widać tu wyraźnie pochylenie się poety nad człowiekiem. Naszkicowana została intymna i tragiczna zarazem chwila samotności konkretnej jednostki. Wyostrzony zmysł obserwatorski pozwolił poecie wybrać drobną scenę i zinterpretować ją w niespodziewanym kontekście. Jak zauważa Wojciech Kudyba: „Pasierb wielokrotnie daje do zrozumienia w swych wierszach, iż nie zadowala go codzienna logika zdarzeń, pasjonują go natomiast sytuacje, w których odkrywamy jakiś rodzaj «wyższej rzeczywistości» przekraczającej nasze dotychczasowe wyobrażenia"11. Gdyby podmiot mówiący pozostał jedynie przy zaobserwowanym obrazie, tekst stałby się suchą rodzajową scenką. Dzięki metafizycznemu naddatkowi wiersz zyskuje wymiar głębszy. Widać tu zatem zainteresowanie Pasierba człowiekiem, przy jednoczesnym zawierzeniu Bogu. Tadeusz Linker zaznaczył, że poeta „starał się pokazać człowieka oddanego całym sobą, niekiedy bezwiednie, Bogu i Miłości, i poddanego cierpieniu i śmierci”" Nazareński Jezusie" jest niejako nadpisany nad postacią, włożony w usta zrozpaczonej osoby. Nieistotny staje się fakt, czy portretowana postać „rzeczywiście” chciałaby wymówić tego typu wezwanie. Pasierb uchwycił w tym spokojnym, choć pełnym napięć utworze ludzką potrzebę wezwania Boga w sytuacji kryzysu. Wiersz stał się zapisem doświadczenia ludzkiego, które rodzi się na przecięciu liryczności i myślenia religijnego.

Rola poety jest wyraźnie zaznaczana w twórczości Pasierba, wiersze autotematyczne znaleźć można w każdym jego tomiku. Poeta to

\footnotetext{
10 Janusz St. Pasierb, Czarna skrzynka, Pelplin 2006, s. 21.

11 Wojciech Kudyba, Rana która przyzywa Boga..., dz. cyt., s. 170.

12 Tadeusz Linker, W misji słowa. Twardowski, Pasierb, Damrot, Św. Wojciech. Tydzień Kultury Chrześcijańskiej w Kościerzynie 1994-1998, Pelplin 1998, s. 168.
} 
ten, kto zapisuje doświadczenie i odpowiada na wezwania rzeczywistości. Ilustruje to na przykład wiersz afrykański:

afrykański wiersz o lwie i gazeli

powiada że oboje

muszą umieć biegać

żeby przeżyć

i że właściwie każdy

musi co rana

zaczynać swój bieg

tak dziś wygląda świat

ale poeta $\mathrm{w}$ tej sytuacji powinien

od czasu do czasu wołać

zatrzymaj się bez względu na to

czy uciekasz czy ścigasz

bo nigdzie

ani przez chwilę

nie będzie ciebie

naprawdę $e^{13}$

Uwagę zwraca ostatnia część utworu. Oprócz podkreślenia roli poety, któremu w tym przypadku przypisano funkcję tego, który ma dawać impuls do refleksji i zatrzymywać bieg codzienności, widać wyraźnie zainteresowanie kondycją człowieka. W wierszu uwypuklone zostało przejście od kultury animalnej - opartej na instynktach - do kultury refleksyjnej. Poeta, jako przedstawiciel tej drugiej, ma rolę przewodnika w codzienności wymagającej życia w przyśpieszonym tempie. Ostatnie wersy wskazują tragizm codziennej egzystencji - bez zatrzymania nie ma szans na prawdziwe życie. Poeta jest tym, który przez zatrzymywanie migotliwej rzeczywistości daje szansę na przetrwanie.

$* * *$

13 Janusz St. Pasierb, Puste tąki, Pelplin 2001, s. 36. 
Omówione przykłady pokazują, że poezja księdza Janusza St. Pasierba jest poezją ludzkiego doświadczenia. Spotkanie z nią to właściwie spotkanie z drugim człowiekiem. Poeta ukazany w wierszach Janusza Pasierba nie jest osobą przeciętną - jest posłańcem skierowanym ku światu i ludziom, ale wybranym przez Boga. Zadaniem poety jest notowanie doświadczenia ludzkiego. Napięcie ogniskuje się wokół opozycji doświadczone-zapisane. A skoro rola poety wiąże się z notowaniem rzeczywistości, to podstawowym narzędziem do tego służącym jest obserwacja.

W Obrocie rzeczy poeta pisze:

Rozliczne zajęcia pochłaniają wiele mojego czasu, a to odbija się negatywnie na pisaniu poezji, na szczęście z dużym zyskiem dla literatury. Poezja jest wewnętrznym barometrem człowieka, jego rozproszenia bądź skupienia. Niemcy mają dobre słowo na jej określenie - Dichtung, co znaczy zgęszczanie. Poezja to zgęszczenie treści. Proch rozsypany pali się wolno, sycząc; zamknięty w komorze pistoletu wybucha. Podobnie ma się rzecz z poezją. Gdy poeta jest niezdolny do koncentracji, to i poezja jest powierzchowna ${ }^{14}$.

Przytoczony fragment wskazuje na troskę poety o skumulowanie treści w niewielkiej poetyckiej formie. Pasierb podkreślał szczególną konieczność zmagania się ze słowem w twórczości poetyckiej - słowa trzeba było oswajać, by móc zamieszkać w rodzimym języku, a następnie zachować czujność, by weryfikować prawdę w codziennym życiu.

W rozmowie ze Zbigniewem Herbertem, która została zamieszczona w tomie Zgubiona drahma, Pasierb po opowieści Herberta o autentycznej i głębokiej wierze swojej babki, dodaje:

Zazdroszczę panu tego wyposażenia na życie. Ale jakikolwiek by był punkt wyjścia, trzeba przejść przez doświadczenia osobiste. Nawet wiara, a może zwłaszcza wiara, poddana jest nieustannie prawu kryzysu ${ }^{15}$.

14 Janusz St. Pasierb, Obrót rzeczy, Pelplin 2002, s. 10.

15 Janusz Stanisław Pasierb, Dramat, który nadaje nam godność. Rozmowa ze Zbigniewem Herbertem, w: tegoż, Zgubiona drachma. Dialogi z pisarzami, przedm. Stefan Frankiewicz, Warszawa 2006 , s. 54 . 
Doświadczenie jest tym, co weryfikuje wiarę i życie. Zbierając rozproszone dotychczas obserwacje, można powiedzieć, że rola poety polega na kumulowaniu doświadczonej rzeczywistości za pomocą poetyckiego słowa. Prawu kryzysu, o którym pisał Pasierb, podlegają niemal wszyscy bohaterowie jego wierszy. Wiersz Prywatnie pokazał, że człowiekowi dane jest doświadczenie Boga, ale nie zawsze potrafi po nie sięgnąć - w sytuacjach trudnych wezwanie Boskiego imienia przychodzi mimowolnie. Tak też bywa w twórczości Pasierba: Bóg zajmuje miejsce centralne, ale objawia się za pomocą ludzkiego doświadczenia, które z kolei nie zawsze jest w pełni zrozumiane przez bohaterów wierszy. Codzienność dotyka Tajemnicy, którą poeta ma szansę rozszyfrować.

W tytule posłużyłam się formułą „obserwacja i trwanie”. Nie jest to bynajmniej zestawienie przypadkowe. Poeta bowiem z reporterską dokładnością i starannością odnotowuje to, co dostępne zmysłowo, ale zdając sobie sprawę z uwikłania w czasie i przestrzeni ludzkiego doświadczenia, zawiera w swojej poezji pewien naddatek - odrywa doświadczenie od horyzontalnie zorientowanego świata, zanurzając je w rzeczywistości transcendentnej. Można powiedzieć, że poezja ta opowiada o zbawieniu, ale za pomocą notowania doświadczeń dostępnych bezpośrednio, bez teologicznej spekulacji. Potwierdza to chociażby wypowiedź z Obrotu rzeczy:

Sądzę, że poezja chrześcijańska musi wyciągać wnioski z faktu Wcielenia. Przecież Bóg stał się człowiekiem, a Słowo ciałem. Poezja, pozostając wierna Bogu, musi jak on być zakochana w świecie stworzonym, widzialnym, dotykalnym, zwłaszcza w człowieku, który jest jednością psychofizyczną ${ }^{16}$.

Wątków teologicznych nie można zamykać wyłącznie w wykazie motywów i nawiązań do biblijnego świata. Poezja Pasierba to spojrzenie na konkret i ciało jako na widzialne i dostępne człowiekowi sygnały metafizyczne. Ks. Jan Sochoń, charakteryzując twórczość poety, wska-

$\overline{16}$ Janusz St. Pasierb, Obrót rzeczy, dz. cyt., s. 11. 
zywał wielokrotnie na bliskość tkanki codzienności w tej poezji, a także na niezwykłą sensualność opisów ${ }^{17}$. Jak podkreśla: „Człowiek nie istnieje tu, na ziemi, w jakiejś wyizolowanej z materii przestrzeni duchowej, lecz ogarniają go żywioły ziemskie: ciała, przestrzeni i czasu"18.

Trwanie tej poezji to w rzeczywistości trwanie przy człowieku jego radościach i smutkach. Poezja zatrzymuje czas ludzkiego działania, otwierając je na przestrzeń transcendencji. Czas ludzki zastyga, gdy wkracza pierwiastek Boski.

Na początku przytoczyłam fragment szkicu Czesława Zgorzelskiego, w którym charakteryzował on istotę twórczości (głównie poetyckiej). Akt twórczy traktował jako reakcję na rzeczywistość, widzianą przez konkretny, działający podmiot. Lektura poezji ks. Janusza St. Pasierba, dzięki temu, że występuje w niej podmiot bacznie obserwujący świat i ludzi, pozwala zauważyć typowe dla twórczości lirycznej przejście od drobnej obserwacji do zobiektywizowanego doświadczenia. Obserwacja i trwanie to filary myślenia o liryczności, a wiersze Pasierba pokazują, jak perspektywa wieczności utrwala wartość pojedynczego doświadczenia.

17 Ks. Jan Sochoń, Geografia zbawienia, w: Ksiadz Janusz St. Pasierb - kapłan, poeta, człowiek nauki. Materiały z sesji w pierwsza rocznicę śmierci (Pelplin - Wyższe Seminarium Duchowne, 15 grudnia 1994 rok), Pelplin 1995, s. 18-23.

18 Tamże, s. 21. 